\title{
Tree Care and Topping Beliefs, Knowledge, and Practices in Six Western U.S. Cities
}

\author{
Michael R. Kuhns and Douglas K. Reiter
}

\begin{abstract}
A survey of households was conducted in six cities in the interior western United States to determine homeowners' knowledge of tree biology and tree care and their knowledge and practice of topping. Tree biology and tree care knowledge was low, depending on the specific subject, and few respondents had any formal training in tree care. Respondents' topping knowledge was moderate to poor if they had topped trees before, regardless of whether they received a topping-related educational brochure. Those who had not previously topped trees were fairly knowledgeable and the brochure increased knowledge in some cases. Topping was fairly commonly practiced, even by those who cared about trees, and often was done for safety and to improve tree appearance and tree health. Amongst those who had topped trees, the survey explored who performed the topping, why it was done, and their satisfaction with the practice. Examples of ways the tree care industry and others may be contributing to misunderstanding, such as inconsistent practices, are discussed. Recommendations are made for changing knowledge and attitudes about tree care as well.

Key Words. Planting; Pruning; Topping; Tree Care; Urban Forestry.
\end{abstract}

Peoples' knowledge of tree biology and tree care may affect whether and how they care for their trees, whether they understand the need to hire an arborist to work with their trees, their perceptions of the quality of tree care, and possibly even their support of and feelings about those working in arboriculture and urban forestry. It also seems likely that support for or condemnation of poor tree care practices (e.g., topping) is affected by peoples' knowledge level. Through twenty years of extension forestry work providing tree care education, this study's authors have found that the least publicly understood tree and tree care subjects are general tree biology, tree roots and soils, planting techniques, fertilization, and pruning. The authors have also observed that arborists and urban foresters often misunderstand these same subjects.

Topping is an especially troublesome practice in which trees are indiscriminately pruned with heading cuts, leading to poor wound closure, decay, and prolific sprouting (Karlovich et al. 2000). Topping is apparently performed to make trees smaller, reduce hazard, and promote vigor. The practice has been the target of public relations campaigns (e.g., the National Arbor Day Foundation's "Don't Top Trees" bulletin; Fazio 1989), but still is fairly common. Kuhns et al. (2005) reported that 57\% of communities in the state of Utah reported significant topping of private trees, though only $14 \%$ of communities topped public trees. Topping of public trees was similarly low in California (20\% of street and park trees) (Thompson and Ahern 2000), but $75 \%$ of northeastern Pennsylvania communities reported that trees were being topped or incorrectly pruned (Elmendorf et al. 2003). In Missouri, $12 \%$ of the street trees examined in 44 communities in 1999 had been topped (Gartner et al. 2002). Karlovich et al. (2000) found that $27 \%$ of trees in four southern Illinois communities appeared to have been topped.

Limited information exists on attitudes, knowledge, and practices of individuals regarding tree care and topping. Close et al. (2001) studied knowledge and attitudes about topping of trees in Illinois, finding that people generally did not understand the consequences of topping. Fazio and Krumpe (1999) studied the same subject in the state of Idaho. They found that people who top trees usually decide to do so based on incorrect notions about trees and tree care, and that over one-third of tree care companies in the area offered topping as one of their services. They also found that people were largely ignorant of tree care practices, with only six percent of respondents getting more than a $50 \%$ score on an eight-question tree care quiz. Schroeder et al. (2003) reported that $55 \%$ of those responsible for public tree care in Illinois communities had no tree-related training.

This study's objectives were to examine whether the public in six western U.S. cities understood a number of important and easily misunderstood arboricultural concepts and practices related to tree root systems and root care, planting, pruning, and fertilization. It examined what people know and feel about topping, whether they have topped, why, who did it, and the effects of receiving an anti-topping educational brochure on their knowledge and feelings. The study also examined what tree education sources people used and their trust in those sources. The overall objective was to find out what people know and do not know about tree care so education can be more effective.

\section{METHODS}

In 2004, a mail survey was conducted of households in the interior western U.S. cities of Boise, Idaho; Salt Lake City, Utah; Phoenix, Arizona; Albuquerque, New Mexico; Denver, Colorado; and Cheyenne, Wyoming. All six cities are the largest cities and the state capitals in their respective states (with the exception of Albuquerque), and all six are Tree City USA cities (NADF 2008a). The primary reason for the survey was to 
characterize peoples' knowledge of and feelings about utility pruning (Kuhns and Reiter 2007), but it also dealt with their tree care knowledge and topping knowledge and practices.

In each city, 350 randomly selected households were mailed a self-administered questionnaire with an introductory letter and a nine-page survey booklet. The cover letter requested the survey be filled out by the adult, 18 years or older, in the household who most recently had a birthday. The survey booklet contained three sections covering tree care practices and issues (including topping), utility pruning, and background and demographic information, including gender, education, income (recoded to categories), home ownership status, and years at their present address. The utility pruning material was covered in Kuhns and Reiter (2007) and will not be dealt with here. Half of the households in each city also were sent a simple brochure titled "Trees and Powerlines" that described what topping looks like and why it should no longer be performed on trees under power lines (Kuhns 1995). If a recipient received the educational brochure they were asked to read it before completing the questionnaire; otherwise the questionnaires were identical.

The questionnaire assessed tree care knowledge by presenting seven statements and asking respondents to indicate Agree or Disagree then recoding the answers as correct or incorrect (or did not know). This was meant to assess participant knowledge while avoiding the feeling of taking a test, similar to the technique used by Fazio and Krumpe (1999). The statements were as follows (the answer judged as correct is in parentheses):

1. Fertilization usually is needed to keep trees healthy (disagree).

2. Trees should be planted deeper than they were grown in the nursery (disagree).

3. Root ball packing materials should be removed when trees from a store or nursery are transplanted (agree).

4. Tree roots need oxygen to survive (agree).

5. Fertilizing trees feeds them (disagree).

6. Most tree roots are fairly shallow (agree).

7. Trees that normally grow large can be kept smaller by pruning without harming them (disagree).

The survey asked respondents to rate their knowledge of urban trees and the care of said trees, and to rate the importance to them of urban trees, on five-point Likert scales from very low to very high, and to indicate the number of tree-care related seminars, classes, or workshops they had attended as an adult. The survey also asked respondents to indicate their sources for urban tree-related information and education by selecting from a list (they could also indicate that no assistance was needed), and to indicate their trust in each source on a four-point scale $(1=$ No Trust, 2 = Low Trust, 3 = Moderate Trust, 4 = Full Trust).

To assess topping knowledge and attitudes, topping was first defined in a fairly nonnegative way as "the practice of rounding over or cutting back a tree's crown, usually to keep it smaller than it would normally grow," and showed three photographs of moderately to severely topped trees. The survey then presented eight statements and asked respondents to indicate Agree, Disagree, or Do Not Know; responses with the correct answer were based on the author's judgment of what would likely be chosen by professional arborists. For all statements, our judgment of what was correct was not revealed to the respondents. Note that two of the statements arguably had no correct answer. These statements were as follows (the answer judged as correct is in parentheses):

1. Topping benefits a tree by letting in more light (disagree).

2. Topping decreases tree health (agree).

3. Fast growth after topping is a sign of good tree health (disagree).

4. Topping improves a tree's appearance (opinion; no correct answer).

5. Topping makes a tree more likely to become a hazard in the long-run and hurt someone or damage their property (agree).

6. Topping is a good way to help prevent insect or disease problems (disagree).

7. Topping is destructive and should not be done (opinion; no correct answer).

8. Wounds on topped branches are easily healed or sealed over by new growth (disagree).

Topping practice was assessed first by asking respondents to indicate whether they had ever topped a tree or had someone top for them (Yes; No). Then they were asked to indicate who topped for them and why (lists of possibilities were supplied, or they could check Other and indicate). Finally, respondents rated their satisfaction with the topping results on a five-point Likert scale from very low to very high.

Surveys were mailed in early 2004, including an initial mailing with a cover letter and self-addressed stamped return envelope, mailing of a reminder postcard, and a second full mailing to those who had not returned the survey (Dillman 2000). Of the 2100 questionnaires mailed, 1786 were delivered and 384 returned for a $21.5 \%$ overall response rate. Ten percent of the nonrespondents were phoned and asked a sample of the survey questions, including several of the demographic questions, to characterize differences between respondents and nonrespondents. Response rates for individual questions/statements ranged from $96 \%-100 \%$ except for income, which was answered by $72 \%$ of respondents. Data compilation and statistical analysis was done using SPSS software. $\chi^{2}$ was used to determine significance of association between nominal or ordinal variables and t-tests were used to determine mean significant differences, with $\alpha=0.05$.

\section{RESULTS AND DISCUSSION}

\section{Response Rate and Nonrespondent} Characteristics

Because of the fairly low response rate $(21.5 \%)$, survey authors phoned $10 \%$ of nonrespondents in each city (141 total) to see how they differed from respondents. Respondents in comparison to nonrespondents were significantly older (mean age 54 versus 50 years; $\mathrm{t}=2.395 ; P=0.017)$, more likely to be male $(57 \%$ male versus $\left.38 \% ; \chi^{2}=11.573 ; P<0.001\right)$, and had spent more time in their present home (15 versus 12 years; $\mathrm{t}=2.690 ; P=$ $0.008)$. They did not significantly differ in educational attainment $\left(\chi^{2}=8.776 ; P=0.118\right)$, income $\left(\chi^{2}=1.980 ; P=0.577\right)$, or home rental/ownership status $\left(\chi^{2}=1.825 ; P=0.177\right)$. Respondents also did not significantly differ from nonrespondents in their 
self-assessed urban tree knowledge $\left(\chi^{2}=4.105 ; P=0.392\right)$ or in the number of tree-related workshops attended $(\mathrm{t}=-0.369 ; P$ $=0.712$ ). However, respondents significantly differed from nonrespondents in the importance of trees to them $(78.9 \%$ high or very high importance versus $60.3 \%$, respectively; $\chi^{2}=15.021 ; P$ $=0.005)$ and in the proportion who had topped a tree $(37 \%$ had topped versus $62 \%$ of nonrespondents; $\chi^{2}=20.568 ; P<0.001$ ).

In topping-related knowledge and attitudes, respondents were significantly more likely than nonrespondents to correctly respond to the statements: "Topping benefits a tree by letting in more light" (Disagree was the correct answer; $\chi^{2}=7.052$, $P=0.008$ ), and "Topping decreases tree health" (Agree; $\chi^{2}=$ $6.795, P=0.009)$, but were not significantly different in their response to "Fast growth after topping is a sign of good health" $\left(\chi^{2}=3.369, P=0.066\right)$. Finally, respondents were significantly more likely than nonrespondents to Disagree that "Topping improves a tree's appearance" $\left(\chi^{2}=5.302, P=0.021\right)$, and to Agree that "Topping is destructive, and should not be done" $\left(\chi^{2}=3.514, P=0.019\right)$. Note that only respondents who did not receive a brochure were used in these topping statement comparisons because those who were phoned did not receive the brochure, which also included negative information about topping.

These differences between respondents and nonrespondents should be taken into account when considering the applicability of the findings to the overall population of those six cities. In particular, it appears that respondents are much less likely to have topped trees than the general public in these cities, a point that seems particularly relevant to this paper's discussion of topping knowledge and practice.

\section{Tree and Tree Care Knowledge}

Responses to the seven statements about tree fertilization, planting, roots, and pruning (agreement or disagreement with the seven tree/tree care statements listed in the methods) are summarized in Figure 1. Among the seven statements, "do not know" responses ranged from 15 to $33 \%$. One statement was answered correctly by the majority of respondents $-80 \%$ knew that tree roots need oxygen to survive (Figure 1). Most respondents were incorrect in their answers to the other six statements.

The greatest misconception had to do with fertilization terminology $-92 \%$ of respondents incorrectly believed that fertilizing trees "feeds" them (Figure 1). This response was understandable, since professionals often refer to fertilization as "feeding" and

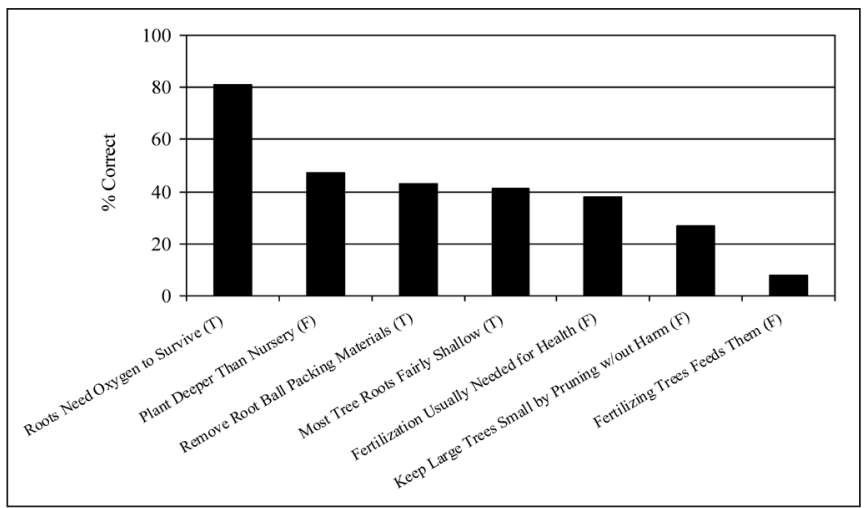

Figure 1. Percentage of respondents correctly answering questions on tree and tree care (correctly agreeing or disagreeing with statements) ( $T$ = True, $F=$ False). have so since the 1920s (Struve 2002). A Google internet search for the terms "tree feeding" performed by the authors in August 2008 yielded many commercial mentions of fertilization as feeding, and the second highest hit was a noncommercial 2004 news release from Kansas State University Research and Extension (Ward 2004) titled "Tree-feeding time a dormant matter," which used the terms "feeding" and "meal" in describing fertilization.

In another statement related to fertilization, $61 \%$ of respondents incorrectly agreed that fertilization is usually needed to keep trees healthy (Figure 1). Researchers, arborists, and urban foresters certainly disagree about whether fertilization is needed for tree health (Struve 2002; Ferrini and Baietto 2006). The American National Standards Institute (ANSI) A300 tree fertilization standard states that the reason for fertilization should be "to supply nutrients determined to be deficient to achieve a clearly defined plant management objective" (ANSI 2004). However, what constitutes an acceptable plant management objective or a deficiency is not defined. This ambiguity, coupled with marketing of routine fertilization by some businesses (based on timing rather than a measured deficiency), might explain confusion amongst both professionals and nonprofessionals.

A majority of respondents were also incorrect about root depth, with $41 \%$ correctly agreeing that most tree roots are fairly shallow (Figure 1). The International Society of Arboriculture's "Trees Are Good" public outreach program makes progress toward countering this misconception with an educational message that emphasizes the shallowness of tree root systems and the futility of deep root fertilization (ISA 2007). Belief in deep roots was perhaps reflected in the incorrect belief by a majority of respondents $(53 \%)$ that trees should be planted deeper than they were grown in the nursery (Figure 1). Some confusion may be due to the prevalence of deep root collars in nursery stock, but recent research on the effects of these problems and efforts to correct them during production may help end this confusion and clarify the message that root collars need to be at or near the soil surface (Watson and Hewitt 2006; Arnold et al. 2007).

Less than a majority of respondents $(43 \%)$ correctly agreed that root ball packing materials should be removed when trees are transplanted (Figure 1). It seems that most arboricultural professionals would agree that twine tied around trunks and containers should be removed. Yet disagreement remains amongst professionals about removal of wire baskets and burlap. The authors of the survey have encountered retail nurseries that void their warranty if packing materials are removed. Appleton and Floyd (2004) showed a clear consensus amongst researchers that most wire baskets should be removed or heavily altered at planting time. She also noted, however, that some growers were recommending that baskets be left in place. Burlap removal recommendations range from remove-none to remove-all, with little research to back-up those recommendations (Kuhns 1997).

Finally, almost three-quarters $(73 \%)$ of respondents agreed that large-growing trees can be kept smaller by pruning without harm (a response judged as incorrect) (Figure 1). Uncertainty was high however, as more checked Do Not Know for this statement than for any other (33\%). Once again, there also appears to be considerable disagreement amongst professionals with these ideas or at least with the terminology (Harris 1994; Ryan 1994).

These results match well with respondents' self-assessed ratings of their knowledge about urban trees and their care, which was rated fairly low with $56 \%$ of respondents rating 
their knowledge very low or low, and only $8 \%$ rating it high or very high (previously reported by Kuhns and Reiter 2007). Their self-rated knowledge varied significantly with gender $\left(\chi^{2}=11.618, P=0.020\right)$, with females rating their knowledge lower than males (63\% low or very low versus $52 \%$ for males). The number of tree workshops or seminars respondents had attended was low, with $287(81 \%)$ indicating none, and $37 \%$ of those who had attended indicating just one workshop, $31 \%$ two, $27 \%$ three to eight, and $7.5 \%$ indicating ten or more workshops.

\section{Tree Topping Practice}

Over one-third ( $37 \% ; n=137)$ of survey respondents had topped their trees. The proportion who had topped was not significantly affected by their feelings about the importance of trees $\left(\chi^{2}=\right.$ $0.639 ; P=0.730)$, with almost identical proportions having topped whether they rated tree importance very low or low $(37.5 \%)$, or very high or high $(36.5 \%)$. The proportion who had topped was significantly affected by agreement with the statement that "topping is destructive and should not be done" $\left(\chi^{2}=25.097, P<\right.$ 0.001 ), with $55 \%$ of respondents who disagreed with this statement having topped. That said, $24 \%$ of those who agreed with this statement still had topped trees. Topping occurrence varied significantly by age $\left(\chi^{2}=27.459 ; P<0.001\right)$ and by home ownership $\left(\chi^{2}=5.046 ; P=0.025\right)$, with $54 \%$ of respondents over 65 years old having topped trees versus $15 \%$ of those aged 21 to 35 years; and $38 \%$ of home owners having topped versus $27 \%$ of renters.

Forty percent of respondents did their own topping, followed closely by utilities (Figure 2). Satisfaction with the results of topping was high, with $41 \%$ of respondents rating their satisfaction as high and $10 \%$ rating it very high. Overall satisfaction did not vary significantly by age, gender, income, education, or home ownership. Satisfaction varied significantly by the source of the topping $\left(\chi^{2}=21.586 ; P=0.042\right)$ (Figure 2). Respondents were most satisfied with topping done by an arborist or a friend, with $71 \%$ and $67 \%$ respectively indicating high or very high satisfaction (Figure 2). Satisfaction was lowest if a utility did the topping, with $36 \%$ indicating high or very high satisfaction, and $34 \%$ indicating low or very low satisfaction. Close et al. (2001) also found that dissatisfaction with utility "topping" was high in Illinois, with $65 \%$ of homeowners dissatisfied. Most respondents to this paper's study who commented on topping satisfaction mentioned tree appearance, with more than half $(58 \%)$ indicating that they were satisfied with the topped tree's appearance. Amongst the positives mentioned were lush regrowth, better shape and size, and improved health. Negatives included poor (often lop-sided) shape and appearance, perceived poor health, and not having been notified before the topping.

The number one reason given for topping trees was safety, with $49 \%$ of respondents topping at least partially for that reason (respondents could check more than one reason) (Figure 3). Size reduction, improving appearance, damage repair, and increasing vigor or health also were cited fairly often as reasons for topping, by $19 \%-44 \%$ of respondents. Satisfaction did not vary significantly $\left(\chi^{2}=19.275 ; P=0.255\right)$ by the reason for topping, and was fairly high for most reasons $(50 \%$ or above rating it high or very high, except $10 \%$ for Told To). The majority of comments about reasons for topping mentioned a requirement by the electric utility to top the tree, which may indicate misunderstanding of what topping is since all of the utilities involved

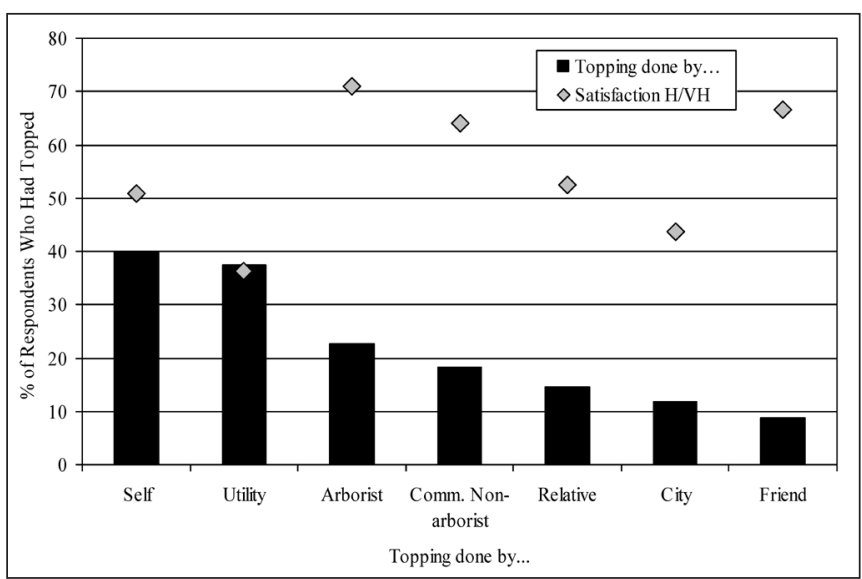

Figure 2. For respondents who had topped trees, the proportion who had a particular type of person/entity do the work (bars) and the proportion who rated their satisfaction with the results as high or very high (diamonds).

in these six cities have a policy not to top trees as indicated by their Tree Line USA status (NADF 2008b). Fazio and Krumpe (1999) in Idaho and Close et al. (2001) in Illinois also found that safety and size reduction were major reasons for topping, though topping for appearance was much less common (only $3 \%$ in Idaho and $16 \%$ in Illinois, versus this study's result of $36 \%$ ).

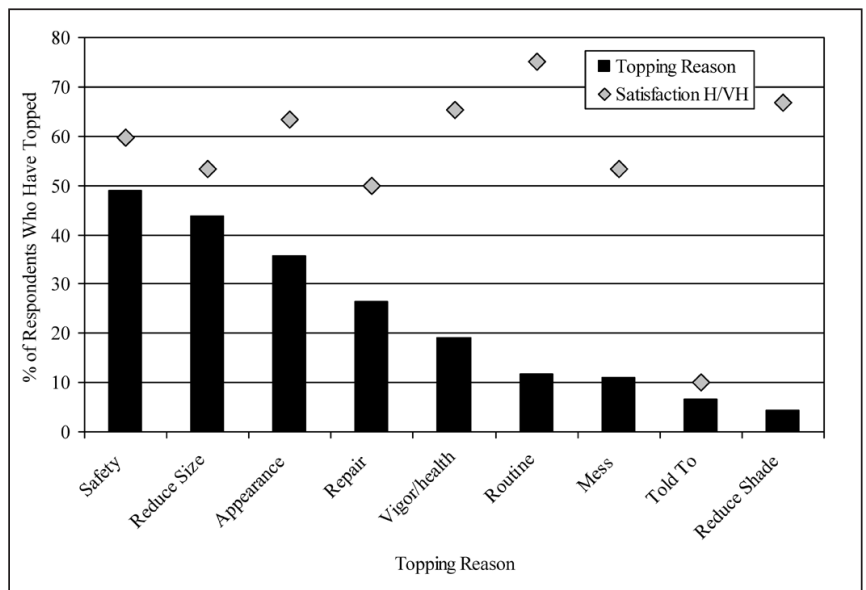

Figure 3. For respondents who had topped trees, the proportion indicating particular reasons for topping trees (bars) and the proportion who rated their satisfaction with the results as high or very high (diamonds).

\section{Tree Topping Knowledge}

For all but one of the topping knowledge statements described in the methods, respondents who had not topped before were significantly more knowledgeable about topping than those who had topped, regardless of whether they received the anti-topping/ utility pruning brochure (Figure 4$)$. Nearly all respondents (83\%94\%) who had not topped trees were correct that 1) topping does not benefit a tree by letting in more light and 2) topping does not prevent insect and disease problems. Correct agreement/ disagreement with the following four statements gradually declined for those who had not topped trees: 1) topping wounds 
are not easily healed or sealed over by new growth, 2) topping decreases tree health, 3) fast growth after topping is not a sign of good tree health, and 4) topping makes a tree more likely to become a hazard in the long run and hurt someone or damage their property. A similar pattern occurred for respondents who had topped trees, but they were much less likely to be correct. Those who had topped were one-third to one-half as likely to be correct as those who had not topped. The brochure only significantly affected answers of those who had not topped, and then only for the middle four statements. It never had an effect on those who had topped, indicating that their beliefs about topping may be fairly deep-seated and not easy to change with education.

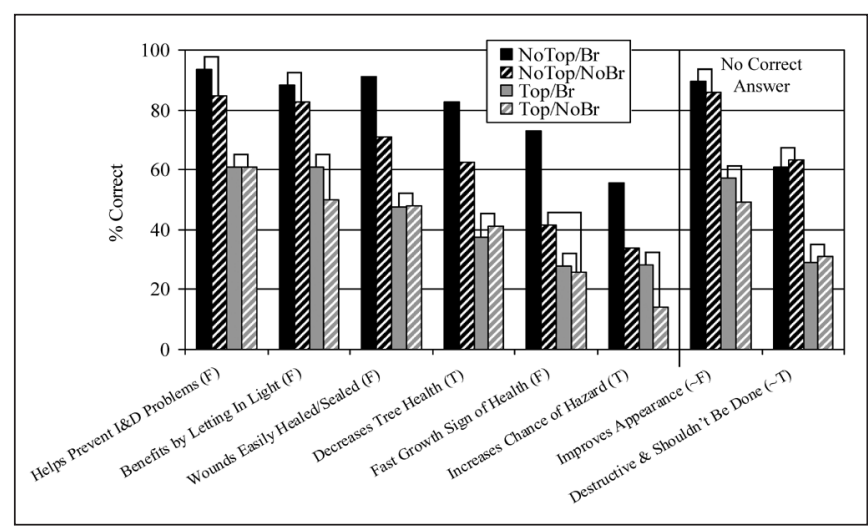

Figure 4. Percentage of respondents correctly answering questions on topping and its effects (correctly agreeing or disagreeing with statements) ( $T=$ True, $F=$ False; note that two have no correct answer). Bars are included for those who have not or have topped a tree (NoTop/Top) with or without a brochure (Br/NoBr). Statistical comparisons were made for each statement on the effects of topping and receiving the brochure, with bars that are not significantly different $\left(\chi^{2} ; \alpha=0.05\right)$ joined by lines.

Most (86\%-90\%) of those who had not topped disagreed that topping improves a tree's appearance (Figure 4). Predictably, those who had topped trees were much more equivocal about this statement, with about half (49\%-57\%) thinking it improved appearance. A majority of those who had not topped before (approximately $60 \%$ ) felt that topping is destructive and should not be done (Figure 4). Only $30 \%$ of those who had topped agreed. This means that $70 \%$ of those who had topped, and $40 \%$ of those who had not, think that topping is an acceptable practice. In other words, people may think that topping looks bad but they also think that it sometimes is necessary. In comparison, Zhang et al. (2007) reported that $43 \%$ of urban Alabama residents "strongly believed that tree topping is a legitimate tree care option."

Fazio and Krumpe (1999) also found that most people who had topped trees tended to lack knowledge about topping, incorrectly thinking that topped trees are safer or less likely to become a hazard, that extra light from topping benefits the tree, that topping is a good way to prevent insect or disease problems, and that topped branches close over and seal by the growth of new wood. Close et al. (2001) found that about half of people who topped trees believed that topping would increase their tree's lifespan.

\section{Educational Source Use and Trust}

Most respondents $(85 \%)$ felt that they needed information and education on urban trees, and this need did not vary significantly with whether they had topped before $\left(\chi^{2}=0.307 ; P=0.579\right)$. For those who needed information, $46 \%$ used a local nursery or garden center (Figure 5). Use of Extension and the Internet also were high $(25 \%-30 \%)$. Friends, arborists, state forestry agencies, and family members were cited as sources less frequently, with utility foresters and tree nonprofit/volunteer groups cited the least. Fazio and Krumpe (1999) reported use of Cooperative Extension and city foresters as information sources by their respondents in Idaho. Treiman and Gartner (2005) found that Missouri community residents relied most heavily on their local garden center for tree advice.

Respondents' trust in a source of tree information did not necessarily mirror use. Trust is shown in Figure 5 as the proportion giving a source a "Full Trust" rating. Extension and state forestry, both noncommercial information sources, were rated high for trust but moderate to fairly low for use. Nurseries, on the other hand, had high use but fairly low trust. The Internet, friends, and utility foresters had low trust ratings. Other studies have found that Extension was a highly trusted tree/forest information source (Kuhns et al. 1998; Kuhns et al. 2005). Comparatively low use of this source may be a reflection of the Extension system not being as well-known as it used to be (Varea-Hammond 2004). People may use Extension educational resources, like the Master Gardener program and various Extension Web resources, without even realizing the source of the information.

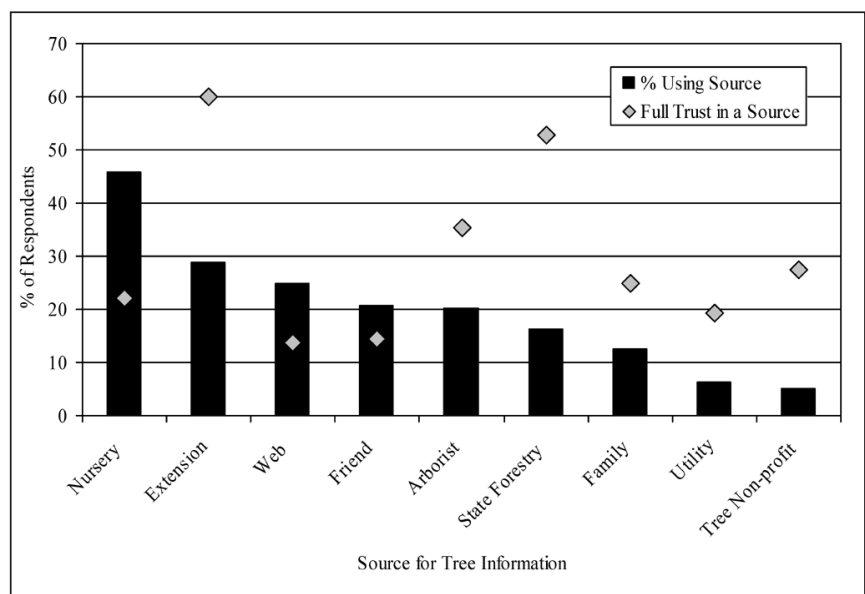

Figure 5. Proportion of respondents using information and education sources about urban trees (bars) and proportion indicating full trust in each source (diamonds).

\section{CONCLUSIONS}

Citizens in the interior West cities studied care about trees but know relatively little about their biology and care and the effects of topping. Many of their misconceptions are shared to some extent by the arboriculture community, possibly leading to confusion over mixed-messages. More and better education of consumers and arborists is needed to counter this lack of knowledge. In addition, arborists need to come to agreement where possible on some of these disputed issues (such as fertilization and planting techniques) so they can speak to the public with one voice. 
Topping is fairly commonly practiced, including by some who seem to know it is detrimental and who feel that trees are important. A favorable impression of topping may be due to a lack of adequate education about its negative effects. We found that having people read a simple educational brochure on directional pruning for utility clearance with some messages about topping was adequate to raise knowledge, but only if they had not topped before. Better education of citizens on tree biology, general care, and topping is desirable, but the form that education takes is important for it to be used and to be effective. Workshops and seminars are good in-depth learning opportunities, but few people avail themselves of those opportunities. People want educational methods and media that are flexible and available when and where they want them (Kuhns et al. 1998). Retail nurseries and garden centers are especially important for getting tree care information distributed because they are commonly used information sources. Extension often is a good source of information and education, but is less used than nurseries, so Extension may want to focus on educating nursery personnel and supplying them with good educational materials. Study of the state of knowledge of nursery/garden center personnel may be useful to see what they know and believe and how that agrees with up-to-date arboricultural knowledge.

People who top trees are likely to be difficult to educate away from their current behavior. They may not be easily swayed by anti-topping educational messages, or at least the messages included in this study's brochure. Good anti-topping materials are available, and Web resources are especially good and thorough, but passive dissemination may not work - if people are convinced that topping is OK or even good, then it seems unlikely that they will go out looking for information about why it is bad. They need to be reached directly with strong anti-topping messages, perhaps through inserts in utility bills, mass media public-service announcements, billboards, booths at garden shows, and through Master Gardener events. Web-based advertisements on gardening and tree-related websites could deliver an anti-topping message, then direct readers to more in-depth materials on the Web. TreeLine USA utilities could help get the anti-topping word out with bill inserts and newsletters, while possibly elevating their status in customers' eyes as professionals who are tree experts and who care about trees (Kuhns and Reiter 2007). This might even help counter the impression people may have that directional pruning done for utility line clearance is topping. Ultimately, anti-topping ordinances, at least for public trees, may be the only way that some people will forego topping.

Working against topping, the arboricultural community cannot rely on its ugliness. Many people who have their trees topped think it looks good. Some even think it looks better than leaving crowns alone. Education needs to focus as directly as possible on why topping is bad for trees despite vigorous regrowth. A strong caution against planting fastgrowing, poor quality trees needs to be part of this education.

\section{LITERATURE CITED}

American National Standards Institute (ANSI). 2004. A300 Standard for Tree Care Operations - Tree, Shrub, and Other Woody Plant Maintenance - Standard Practices (Fertilization, Part 2). American National Standards Institute, New York, NY.

Appleton, B., and S.A. Floyd. 2004. Wire baskets - Current products and their handling at planting. Journal of Arboriculture 30:261-265.
Arnold, M.A., G.V. McDonald, D.L. Bryan, G.C. Denny, W.T. Watson, and L. Lombardini. 2007. Below-grade planting adversely affects survival and growth of tree species from five different families. Arboriculture \& Urban Forestry 33:64-69.

Close, D.D., J.W. Groninger, J.C. Mangun, and P.L. Roth. 2001. Homeowners' opinions on the practice and effects of topping trees. Journal of Arboriculture 27:160-165

Dillman, D.A. 2000. Mail and Internet Surveys: The Tailored Design Method. John Wiley and Sons, New York.

Elmendorf, W.F., V.J. Cotrone, and J.T. Mullen. 2003. Trends in urban forestry practices, programs, and sustainability: Contrasting a Pennsylvania, U.S., study. Journal of Arboriculture 29(4):237-247.

Fazio, J.R. 1989. Don't Top Trees. Tree City USA Bulletin No. 8, J.R. Fazio, Ed. National Arbor Day Foundation, Nebraska City, NE. 8 pp.

Fazio, J.R., and E.E. Krumpe. 1999. Underlying beliefs and attitudes about topping trees. Journal of Arboriculture 25:192-199.

Ferrini, F., and M. Baietto. 2006. Response to fertilization of different tree species in the urban environment. Arboriculture and Urban Forestry 32:93-99.

Gartner, J.T., T. Treiman, and T. Frevert. 2002. Missouri urban forest - A ten-year comparison. Journal of Arboriculture 28:76-83.

Harris, R.W. 1994. Clarifying certain pruning terminology: Thinning, heading, pollarding. Journal of Arboriculture 20(1):50-54.

International Society of Arboriculture. 2007. The top 10 myths of tree care. www.treesaregood.com/pressrelease/press/top10myths.aspx (accessed August 7, 2008).

Karlovich, D.A., J.W. Groninger, and D.D. Close. 2000. Tree condition associated with topping in southern Illinois communities. Journal of Arboriculture 26:87-91.

Kuhns, M.R. 1995. Trees and Power Lines. Leaflet 270, USU Extension. 2 pp.

Kuhns, M.R. 1997. Penetration of treated and untreated burlap by roots of balled-and-burlapped Norway maples. Journal of Arboriculture 23:1-7.

Kuhns, M.R., M.W. Brunson, and S.D. Roberts. 1998. Landowners' educational needs and how foresters can respond. Journal of Forestry 96:38-43.

Kuhns, M.R., B. Lee, and D.K. Reiter. 2005. Characteristics of urban forestry programs in Utah, U.S. Journal of Arboriculture 31:285-295.

Kuhns, M.R., and D.K. Reiter. 2007. Knowledge of and attitudes about utility pruning and how education can help. Arboriculture \& Urban Forestry 33:264-274.

National Arbor Day Foundation (NADF). 2008a. Tree City USA web page. www.arborday.org/programs/treeCityUSA.cfm (accessed 08/15/08).

National Arbor Day Foundation (NADF). 2008b. Tree Line USA website. www.arborday.org/programs/TLUSAReqments.cfm (accessed 8/15/08).

Ryan, H.D.P. III. 1994. Arboricultural pruning methodologies. Arborist News 3(4):33-40.

Schroeder, H.W., T.L. Green, and T.J. Howe. 2003. Community tree programs in Illinois, U.S.: A statewide survey and assessment. Journal of Arboriculture 29:218-225.

Struve, D.K. 2002. A review of shade tree nitrogen fertilization research in the United States. Journal of Arboriculture 28:252-263.

Thompson, R.P., and J.J. Ahern. 2000. The State of Urban Forestry in California. Urban Forest Ecosystems Institute Technical Report No. 9. San Luis Obispo, CA

Treiman, T., and J. Gartner. 2005. What do people want from their community forests? Results of a public attitude survey in Missouri, U.S Journal of Arboriculture 31(5):243-250. 
Varea-Hammond, S. 2004. Guidebook for marketing Cooperative Extension. Journal of Extension 42(2). www.joe.org/joe/2004april/tt5. shtml (accessed March 25, 2008).

Ward, K. 2004. Tree-feeding time a dormant matter. Kansas St. Univ. Res. and Ext. Release, November 11, 2004. www.oznet.ksu.edu/ news/sty/2004/tree_feeding111104.htm (accessed March 25, 2008).

Watson, G.W., and A. Hewitt. 2006. Getting the roots right. American Nurseryman 203:35-39.

Zhang, Y., A. Hussain, J. Deng, and N. Letson. 2007. Public attitudes toward urban trees and supporting urban tree programs. Environment and Behavior 39(6):797-814.

Acknowledgments. Support for this project came from the ISA Duling Grants (now the TREE Fund), and from the Utah Agricultural Experiment Station, Utah State University, Logan, Utah (approved as journal paper number 7967). Also, thanks to the US Forest Service, Pacific Northwest Research Station, Human and Natural Resources Interactions Program for their support in producing this manuscript.

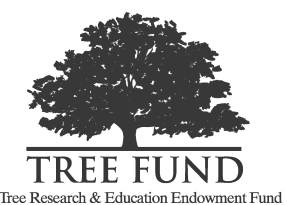

Michael R. Kuhns (corresponding author)

Professor

Department of Wildland Resources

Utah State University

Logan, UT 84322-5230, U.S.

mike.kuhns@usu.edu

Douglas K. Reiter

Research Associate

Institute for Outdoor Recreation and Tourism

Utah State University

Logan, UT 84322-52

Résumé. Une enquête auprès de résidants de maisons a été menée dans six villes de l'intérieur de l'Ouest des États-Unis afin de déterminer leur degré de connaissance sur la biologie et l'entretien des arbres ainsi que sur leurs connaissances et leurs pratiques en écimage. Les connaissances en biologie et en entretien étaient faibles, dépendant du sujet spécifique, et peu de répondants avaient une formation formelle en entretien des arbres. Les connaissances des répondants en écimage étaient modérées à pauvre s'ils avaient déjà étêté un arbre auparavant, et ce en peu importe s'ils avaient reçu une brochure éducative sur l'écimage des arbres. Ceux qui n'avaient pas écimé des arbres auparavant étaient relativement informés et la brochure a permis d'augmenter ces connaissanc- es dans certains cas. L'écimage était une pratique relativement commune, même par ceux qui tenaient beaucoup à leurs arbres, et a été souvent effectuée pour des motifs de sécurité et d'amélioration de l'apparence et de la santé de l'arbre. Parmi ceux qui avaient écimé leurs arbres, l'enquête a exploré les aspects de qui avait effectué l'écimage, du pourquoi cela avait été réalisé et de la satisfaction envers cette pratique. Des exemples de façons que l'industrie arboricole et les autres intervenants peuvent contribuer aux incompréhensions, telles que des mauvaises pratiques, sont discutées. Des recommandations sont aussi faites pour changer les connaissances et les attitudes concernant l'entretien des arbres.

Zusammenfassung. In sechs Städten in den inneren Vereinigten Staaten wurde eine Haushaltsbefragung durchgeführt, um die Kenntnisse der Hauseigentümer bezüglich Baumbiologie, Baumpflege und ihr Wissen und ihre Schnitterfahrung zu erfassen. Baumbiologie und Pflege waren niedrig in Abhängigkeit von dem speziellen Subjekt und einige Teilnehmer hatten geringe Kenntnisse im Baumschnitt. Die Kenntnis im Spitzenkappen von Bäumen war mittel bis niedrig, wenn sie zuvor Bäume geköpft hatten, unabhängig davon, ob sie eine Anleitungs-Broschüre erhalten haben. Diejenigen, die nicht kürzlich einen Baum gefällt hatten, waren ziemlich kenntnisreich und die Broschüre hat in einigen Fällen dazu beigetragen. Spitzenkappen wurde relativ häufig praktiziert, auch von denen, die sich um Bäume sorgten. Oft wurde es wegen Sicherheitsrisiken und zur Verbesserung von Baumerscheinung und -gesundheit durchgeführt. Unter denen, die Bäume geköpft hatten, enthüllte die Umfrage, wer die Arbeit ausgeführt hatte, warum sie ausgeführt wurde und die Zufriedenheit mit dem Ergebnis. Es werden Beispiele aus der Praxis angeführt, wie die Baumpflegeindustrie und andere zu Missverständnissen bei der Ausführung beitragen. Es werden Empfehlungen gegeben, wie Kenntnisse und Verständnis von Baumpflege vergrößert werden kann.

Resumen. Se condujo una encuesta de hogares en seis ciudades en el interior del oeste de los Estados Unidos para determinar el conocimiento de los propietarios de la biología y cuidado del árbol y su conocimiento y práctica del desmoche. El conocimiento de la a biología y cuidado del árbol fue bajo, dependiendo del sujeto específico, y pocos tuvieron un entrenamiento formal en el cuidado de los árboles. El conocimiento en desmoche fue moderado a pobre si habían desmochado los árboles anteriormente, sin importar si habían recibido folletos educativos relativos al demosche. Quienes no habían previamente desmochado árboles eran muy conocedores y el folleto incrementó el conocimiento en algunos casos. El desmoche fue ampliamente practicado, aún por aquellos que cuidaban sus árboles, y con frecuencia hecho para seguridad y mejoramiento de la apariencia y salud del árbol. Entre los que habían desmochado sus árboles, la encuesta exploró quiénes lo realizaron, por qué fue realizado y su satisfacción con esa práctica. Se discuten ejemplos de la industria del cuidado de los árboles que pueden contribuir al mal entendimiento igual que a prácticas inconsistentes. Se hacen recomendaciones para el cambio del conocimiento y actitudes acerca del cuidado de los árboles. 